\title{
Mobilizing food: A review of Building Natume's Market
}

\author{
Review by Corey Lee Wrenn * \\ University of Kent
}

Review of Building $N$ ature's Mark et: The Business and Politics of $\mathrm{N}$ atural F oods, by Laura J. Miller. (2017). Published by the University of Chicago Press. Available as clothbound, paperback, and ebook; 288 pages. Publisher's website: https:/ / www.press.uchicago.edu/ ucp/ books/ book/ chicago/ B/ bo27035081.html

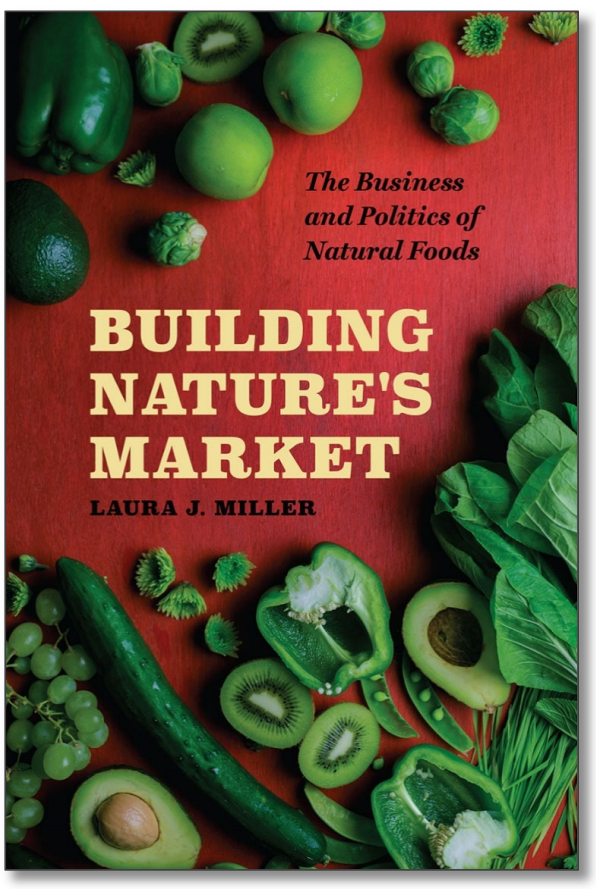

Submitted July 31, 2018 / Published online November X, 2018

Citation: Wrenn, C. L. (2018). Mobilizing food: A review of Building N ature's

Mark et [Book review]. Journal of A griculture, F ood Systems, and Community D evelopment, 8(3), 207-211. https:/ / doi.org/ 10.5304/ jafscd.2018.083.010

Copyright @ 2018 by the Author. Published by the Lyson Center for Civic Agriculture and Food Systems. Open access under CC BY license.

$\mathrm{M}$ iller's (2017) Building $N$ ature's Mark et introduces the American natural foods movement to social movement studies, highlighting its challenge to the prevailing social order related to food, consumption, health, state authority, and individualism. This movement is concerned with more than just food; it tackles no less than society's values about progress as it is generally tied to industrialization and technical innovation. The

* Dr. Corey Lee Wrenn chairs the Animals \& Society Section of the American Sociological Association (for 2018-2021). She is the author of A Rational A pproach to A nimal Rights (Palgrave) and Piecemeal Protest: A nimal Rights in the A ge of $\mathrm{N}$ onprofits (University of Michigan Press). Dr. Wrenn is at the University of Kent in Canterbury, UK. She can be reached at corey.wrenn@gmail.com. book's primary thesis is the argument that the natural foods movement has been propelled not only by activist altruism and perseverance, but also through the innovativeness of savvy capitalist entrepreneurs and corporations.

This argument is distinctive in social movement studies, as many scholars identify corporate cooperation as "selling out" (Chasin, 2000) or capitalist co-optation (Wrenn, 2016; Zeisler, 2016). D espite the clear contradiction created by aligning with a corporate system that was simultaneously problematized, Miller identifies businesses as movement participants. For most of its history, she writes, "... the natural foods movement has to a large degree been constituted by a natural foods industry at the same time as it has retained a cri- 
tique of the corrupting influence of commercialism on the social organization of diet and health" (p. 2). It is "not always the case," she furthers, "that private enterprise stands in opposition to movements for social change" (p. 4).

Miller begins her analysis with a review of the aesthetic roots of the health food industry nurtured by romantics and pseudoscientists such Sylvester Graham, the Alcotts, and John H. Kellogg. By the end of the 19th century, the movement was secularizing, notably prompting natural foods leader Kellogg to split with the Seventh Day Adventists who had nurtured his career so that he could develop what had become a business enterprise. While the Adventists reacted sourly to his eager patent-seeking, advertising, and expansion, Kellogg's emancipation invariably led to the growth of vegetarian products and availability. Even in its early years, it was evident that cooperation with capitalism was correlated with movement success, if success is understood as changing consumption behaviors. For many movement puritans, such as the Adventists, this compromise indicated failure, not victory.

Indeed, social movement scholars understand movement success to be ambiguous and contested (Martin, 2008), particularly given their tendency to factionalize and innovate goals as the collective action progresses (Frey, D ietz, \& Kalof, 1992). Although the religious roots of the natural foods movement were important for sustaining adherents in a society that was hostile and mocking of its health-centrism, most activist-producers across the field eventually dropped their religious framework to appeal to a wider consumer base. This strategy, Miller indicates, annoyed the movement's spiritual purists and demonstrates one of its first instances of factionalism over radicalism and capitalist cooptation. A further point of schism developed from the emergent corporate strategy of framing health food as something that had to be packaged and processed, thus cutting off the public from accessing health food on its own. Natural foods thus ironically transformed into processed foods in order to increase sales and protect its market. This certainly demonstrates a negative consequence of collaborating with capitalism. Movement purity was further threatened by the desire to add salt, sugar, and other flavorings to improve consumer appeal.

D espite the compromises, Miller suggests that this industrialization increased the accessibility of the products. Compromises may have been considerable, but the movement did seize cultural footholds in a particularly hostile environment. Because it questioned the hegemony of the medical, scientific, and state institutions, it predictably garnered considerable resistance. The bulk of countermobilization derived from the efforts of the medical establishment, which felt the most threatened by the movement's desire to reclaim and reframe the meaning of "health." To avoid the medical establishment's state-supported retribution, many purveyors conceded with vague language like "dietary food." Natural food's foothold was further threatened by the American Medical Association's grand effort in the production of literature, films, and outreach programs in tandem with pressure on mainstream media sources, all designed to counter the movement's health-food claims. Because the health-food movement challenged the status quo of farming and food production, the state invested considerable effort into clamping down on said claims, specifically in regard to labeling, but also as it surfaced in books, lectures, and store displays. Miller reports that health-food leaders and purveyors were regularly fined and harassed by state agents who would confiscate literature and products deemed illegitimate. The state even coordinated spies who could obtain insider information to later use to control natural foods efforts.

Along with the First Amendment, libel laws did allow the natural foods movement to persist, but it clearly faced an uphill battle in protecting and advancing its claims-making. As a consequence, Miller argues that the movement took a tactical turn toward individualism by framing its aim as a matter of consumer freedom and self-determination in health. D oing so allowed it to broaden its political base. The movement was also bolstered in the late 1960s and 1970s by the counterculture and environmental movements, notably advantaged by Rachel Carson's Silent Spring (1962), which constituted a mobilizing moment. More young people subsequently adopted natural foods as a political measure. These rapid changes resulted in an ele- 
ment of culture clash as the supplement salespersons who characterized the movement in the decades prior struggled to efficiently cooperate with the looser organizational style of new participants of a countercultural persuasion.

With the affluence of the 1980s, the movement would transform again, moving away from the simplistic back-to-nature ethic of its earlier portrayal toward a higher-class bracket, aligning natural foods with being educated and wealthy. Stores became cleaner, glossier, and more aesthetically pleasing, while natural foods were rebranded as products of the wealthy through price markups, artisanal recipes, and nice packaging. Evoking the Bordieuan concept of distinction (Bourdieu, 1984) and its power to manifest cultural value and reproduce class inequality, Miller credits this stylistic change with finally pushing natural foods into the mainstream.

It was at this time that larger grocers such as Whole Foods began to dominate natural foods retail sales, while the number of distributors dwindled to a just a few, raising some concern regarding the suffocation of smaller, community-based businesses. Power in the field consolidated further with the institutionalization of certification programs and trade organizations, which increased clout in the field and to the public, but dramatically changed the face of the movement, professionalizing it and removing its activist edge. This new wave in the movement lost the small-time feel of its earlier incarnations, which had prioritized personal networks. Smaller producers that could not afford to participate were gradually squeezed out.

The movement's move to standardize brings attention to a common movement tension regarding identity and ideology. McG arry and Jasper (2015) point to an "identity dilemma" as movements must decide boundaries of inclusion and exclusion. G reater inclusion allows a movement to grow, but generally requires a significant compromise to movement ideologies and goals. It became increasingly difficult for the natural foods movement to maintain any semblance of ideological purity as it began producing on a large scale in a capitalist system that is otherwise designed to facilitate exploitative or unhealthful practices. O ne consequence of this growing pain was the fissure that erupted between the supplement industry and natural foods. Many understood supplements not only to be non-foods but, more specifically, nonfoods that risked defaming the movement given regular scandals about their purity and safety. Y et supplements had long been the bread and butter of the movement, allowing it to infiltrate mainstream society (given their scientific aura) and remain financially afloat.

Miller maintains a very forgiving position on capitalist growth in the movement, emphasizing that industry was always, from the very beginning, part and parcel of natural foods activism. The author briefly mentions the erosion of vegetarianism in favor of flexitarianism as an example of how movements must water down their message and abandon purity in order to grow. However, vegetarianism is not just a lifestyle movement, as the author most frequently describes it. It is also part of the social justice-oriented animal rights movement (Maurer, 2002), and thus entails different interests and goals. This is important because the author claims that all movements, and especially lifestyle movements as they are focused on consumption, will inevitably need to work heavily with capitalist enterprise. Some vegan and vegetarian scholars disagree that plant-based eaters, who challenge mainstream consumption patterns, must collaborate with capitalism to succeed (Nibert, 2017; Wrenn, 2016). Capitalism, from this perspective, is the source of speciesism, not the solution.

Furthermore, Miller's identification of business as a contributor to social change provides only a superficial engagement with the problems inherent to this approach (such as the systemic violence against people of color, women, and animals). Sociological theory on the consequences of capitalism is barely mentioned, aside from a nod to Marx's observation that capitalist elites can be toppled by technological changes in the means of production, which allows for entrepreneurs who will replace them. Such a strategy still works in congruence with a system of exploitation and high inequality, however. Miller only seems to explore natural foods as it pertains to people growing and selling food, and only briefly hints at how this turns into organized protest by referring to the rise of trade groups and certification programs. A large body of 
research exists on the relationship between capitalism and food movements (Carolan, 2018; D auvergne \& Lister, 2013; Raynolds, Murray, \& Wilkinson, 2007; Smith, 2017; Torres, 2006; Winders \& Nibert, 2004), but very little of this discourse is mentioned in the book. Instead, the author is primarily committed to engaging general social movement theory and its failure to embrace industry as an agent of change and an oft-ignored movement participant.

Miller also highlights the role of industry in reducing governmental and medical resistance by normalizing the movement as a viable economic sector. This was made possible, she explains, by turning to capitalism over countercultural politics such that the former resistance to state and scientific authority erodes. Alternatively, this weakened resistance could indicate that the movement was successful in challenging these hegemonies in determining personal health and its anti-science frames may have resonated. It may be effective protest, in other words, not capitalist co-optation as she suggests, that propelled the movement. Miller does not engage at all with the literature of the animal rights movement, which discusses how this anti-science element emerges largely due to the systemic violence against animals that has been promulgated in the name of scientific inquiry (Jamison \& Lunch, 1992; Kean, 1995). In fact, her position (that capitalism, more than contentious protest, manifests social change) also counters her previous observations that the natural foods movement actively sought out scientific research to verify its efficacy.

Lastly, the author celebrates big industry as an abeyance mechanism given its ability to hold a movement together and sustain it through rough times. Institutionalization, it is offered, is helpful for longevity. This point is a strong one. As I can attest from my research in the animal rights movement, radical groups that resist institutionalization sprout up and die off with a very short lifespan. Larger organizations are able to weather the tide and maintain cultural authority and movement resources. Their propensity for heavy compromise and dilution of goals, however, calls into question how effective this structure is for attaining just food.

In conclusion, Miller makes a compelling argument for the need to acknowledge industry as a viable actor in the mobilization and success of social movements, especially consumption movements, but it remains to be seen how capitalisma system that requires inequality and encourages overproduction and consumption - will ultimately prove compatible with goals of social health, equality, and justice. It is clear that capitalist pressure is a major influence on social movements, but it is not clear from Miller's analysis how capitalism is expressly a catalyst for movement progress, and not regress.

\section{References}

Bourdieu, P., \& Nice, R. (Trans.).(1984). D istincion: A social critique of the judgment of taste. New Y ork: Routledge.

Carolan, M. S. (2018). The food sharing revolution: $\mathrm{H}$ ow start-ups, pop-ups, and $\infty$-ops are changing the way we eat. Washington, D.C.: Island Press.

Carson, R. (1962). Silent spring. New York: Houghton Mifflin.

Chasin, A. (2000). Selling out: The gay and lesbian movement goes to mark et. New Y ork: Palgrave.

D auvergne, P., \& Lister, J. (2013). E $œ$-business : A big-brand tak eover of sustainability. Cambridge, MA: MIT Press.

Frey, R. S., Dietz, T., \& Kalof, L. (1992). Characteristics of successful American protest groups: Another look at Gamson's strategy of social protest. A merican Journal of Sociology, 98(2), 368-387. https:/ / doi.org/ 10.1086/ 230012

Jamison, W. V., \& Lunch, W. M. (1992). Rights of animals, perceptions of science, and political activism: Profile of American animal rights activists. Science, Technology, \& H uman V alues, 17(4), 438-458. https:/ / doi.org/ 10.1177/ 016224399201700402

Kean, H. (1995). The 'smooth cool men of science': The feminist and socialist response to vivisection. H istory W ork shop Journal, 40(1), 16-38. https:/ / doi.org/ 10.1093/ hwj/ 40.1.16

Martin, A. W. (2008). Resources for success: Social movements, strategic resource allocation, and union organizing outcomes. Social Problems, 55(4), 501-524. https:/ / doi.org/ 10.1525/ sp.2008.55.4.501 
Maurer, D . (2002). V egetarianism: M ovement or moment? Philadelphia, PA: Temple University Press.

McG arry, A., \& Jasper, J. M. (Eds.). (2015). The identity dilemma: Social movements and collective identity. Philadelphia, PA: Temple University Press.

Nibert, D . (Ed.). (2017). A nimal oppression and capitalism. Santa Barbara, CA: Praeger.

Raynolds, L. T., Murray, D ., \& Wilkinson, J. (Eds.). (2007). Fair trade: The challenges of transforming globalization. London: Routledge. https:/ / doi.org/ 10.4324/ 9780203933534

Smith, J. P. (2017). Markets in mothers' milk: Virtue or vice, promise or problem? In M. Cohen \& Y. O tomo (Eds.), Making milk: The past, present, and future of our primary food (pp. 117-138). New Y ork: Bloomsbury. https:// doi.org/ 10.5040/ 9781350029996.ch-007

Torres, B. (2006). Making a killing: The political economy of animal rights. O akland, CA: AK Press.

Winders, B., \& Nibert, D . (2004). Consuming the surplus: Expanding "meat" consumption and animal oppression. International Journal of Sociology and Social Policy, 24(9), 76-96. https:/ / doi.org/ 10.1108/ 01443330410790786

Wrenn, C. (2016). A rational approach to animal rights: E x tensions in abolitionist theory. New York: Palgrave.

Zeisler, A. (2016). W e were feminists once: F rom riot grrrl to C overG irl ${ }^{\circledR}$, the buying and selling of a political movement. New Y ork: PublicAffairs. 